\title{
ogopaedica ocziensia
}

$\mathrm{Nr} 4(2020)$

D0l: http://dx.doi.org/10.18778/2544-7238.04.06

\author{
Monika Kaźmierczak* iD
}

\section{Konceptualizacje głosu}

\section{Voice Conceptualizations}

\author{
Słowa kluczowe: phoné, głos, komunikacja wokalna, komunikacja ustna \\ Keywords: phoné, voice, vocal communication, oral communication
}

\section{Wprowadzenie}

Ludzki głos jest postrzegany w różny sposób i przypisuje się mu różnorodne funkcje. Niejednoznaczności i paradoksy związane ze statusem głosu wskazują, że jest on jednocześnie czymś ulotnym i niemożliwym do stłumienia, korporalnym i językowym, wewnętrznym i zewnętrznym, zoe i bios, należącym do podmiotu i Innym [Michalik, 2010]. Zainteresowanie głosem odnosi się do triady: byt - myśl - sposób jej wyrażania.

W codziennej komunikacji podkreśla się głównie językowe znaczenie głosu: „Największą wartością naszego aparatu głosowego jest możliwość wytworzenia dźwięku artykułowanego. Dzięki niej człowiek rozwinął mowę, która umożliwia mu wzajemną komunikację" [Tarasiewicz, 2006, s. 171]. W interakcji międzyludzkiej to częściej mowa i wyrażany sens, nie zaś sam głos w wymiarze materialnym bądź symbolicznym, stanowią pierwszoplanowy przedmiot analiz mówiącego lub słuchającego podmiotu. Mówienie, czyli przekazywanie znaków językowych za pomocą głosu, to wytwarzanie artykułowanych dźwięków w celu wyrażania myśli - dźwięk staje się głosem, o ile coś wyraża. Co jednak może wyrażać głos i jak jest postrzegany?

\footnotetext{
* Uniwersytet Łódzki, Wydział Filologiczny, Zakład Dialektologii Polskiej i Logopedii, ul. Pomorska 171/173, 90-236 Łódź, e-mail: monika.kazmierczak@uni.lodz.pl, ORCID: https://orcid.org/0000 -0003-4396-3627.
} 


\section{Refleksja korporalna}

Kryzys tradycyjnej władzy wzroku w modernizmie, powrót do ciała i eksponowania cielesności otwierają refleksję nad możliwościami poznawczymi człowieka, jego stosunkiem do siebie. Sposoby postrzegania własnego ciała przez podmiot mogą być różne, wymienia się między innymi konceptualizacje fenomenologiczne, kognitywistyczne, antropologiczne, feministyczne czy te odnoszące się do socjologii ciała (socjologii o ciele). W zależności od sposobu deskrypcji wymagają one ujęcia holistycznego albo redukcjonistycznego. Takie wielowymiarowe rozumienie ciała sugeruje, że pojęcie body-centrism [Wierzbicka, 1985] można rozpatrywać z kilku perspektyw [Maćkiewicz, 2008]:

- jako całkowicie (holizm) bądź częściowo (dualizm: soma - psyche) tożsame z człowiekiem;

- jako element pozostający w posiadaniu danej osoby (bryła poddawana modelowaniu);

- jako mechanizm składający się z powiązanych ze sobą pojedynczych komponentów - części;

- jako pojemnik (konotacje pozytywne: naczynie, worek, mieszkanie; konotacje negatywne: klatka, więzienie).

Ciało może być zatem rozumiane nie tylko jako immanentne z człowiekiem, ale również częściowo lub całkowicie poza nim: „Samo wyrażenie: «moje ciało» budzi zresztą wątpliwości. Moje - to znaczy czyje? Jakiego Ja poza ciałem? Duszy, świadomości samoistnej, niezależnego od ciała psychizmu?" [Skarga, 1997, s. 165]. Przeświadczenie, że ciało jest czymś obcym, osobnym bytem, niepoddającym się wolicjonalnej kontroli, może prowadzić do cielesnej i psychicznej dezintegracji. Dialektyczny ruch pomiędzy bytem (jestem) a posiadaniem (mam) zwraca uwagę na możliwość różnego spojrzenia na relacje ciała i podmiotu. Ciało jest własnością podmiotu czy podmiot należy do ciała? Sytuowana pomiędzy decyzyjnością (chcę: intencjonalność działań, wolicjonalna kontrola, podporządkowanie cielesności rozumowi, dysponowanie ciałem) a mimowolnością (muszę: niezależność od woli podmiotu, wtórne przyzwolenie) potencjalność ciała nieustannie zmieniającego i stającego się jest trudna do uchwycenia i opisu, stąd mnogość metafor i symboli.

Ciało jako sfera graniczna pomiędzy tym, co zewnętrzne (kulturowe) i tym, co wewnętrzne (głębia, świadomość, refleksja), co wychodzące z ciała i przenikające ze świata, „jest miejscem jej indywidualnej i zbiorowej inskrypcji” [Bakke, 2000, s. 9]. Ta dwuwymiarowość wyznacza też dwa aspekty podmiotowości, które powinny uzupełniać się wzajemnie podczas konstytuowania się tożsamości podmiotu, jako elementy nieustannie interpretowane i interpretowalne. Postrzeganie własnego ciała lub jego składowych to ogląd czyniony z pewnej perspektywy, podmiot ma bowiem zdolność transcendowania siebie, kulturowej identyfikacji Ja. Ciało - skomplikowana struktura zapośredniczona przez afekty, emocje, język, nauki o zdrowiu czy kulturę 
- przekracza granicę zarówno tego, co naturalne, jak i tego, co kulturowe. Pozwala spojrzeć na siebie jako na podmiot, a stanowiąc przedmiot oglądu, staje się centralnym punktem refleksji. Psychiczny dyskomfort związany z cielesnością może wynikać z niemożności pełnego wglądu i redukcji doświadczenia do tego, co zewnętrzne. Stosunek podmiotu do własnego ciała, a raczej jego obrazu (wrażeń powierzchniowych - obrazu powierzchni ciała, zmysłowo postrzegalnych części ciała) jest konfrontowany z wizerunkiem ciał Innych podczas kontaktów społecznych.

\title{
Phoné a podmiot, phoné a logos
}

Wielość kierunków refleksji korporalnych wskazuje możliwość występowania różnych relacji pomiędzy głosem i Ja.

\begin{abstract}
„Bycie głosem” odnosi się do odbieranych i przekazywanych wrażeń czy przeżyć. „Posiadanie głosu” wskazuje na jego odseparowanie od Ja, traktowanie w kategoriach zadania, obowiązku, uwzględniającego etos pracy nad głosem. Instrumentalno-uprzedmiotowiający model refleksji traktuje głos jako narzędzie wykorzystywane w codziennym przekazywaniu informacji bądź w pracy zawodowej [Kaźmierczak, 2017, s. 333].
\end{abstract}

Ze względu na różne pojmowanie tych relacji możliwe jest pełne utożsamienie się z głosem, czyli osadzenie się we własnej cielesności. Jednak może też dojść do rozluźnienia czy wręcz zerwania kontaktu z własnym głosem, wówczas jest on traktowany jak element osobny, nierzadko naznaczony chorobą, postrzegany jako zagrożenie dla funkcjonowania organizmu. Głos jest zatem „zjawiskiem istotnym dla sposobu, w jaki doświadczamy samych siebie i innych - jedną z postaci samoodniesienia i jednym z warunków intersubiektywności” [Michalik, 2010, s. 12]. Głos może okazać się jedyną oznaką tożsamości podmiotu komunikującego się, „intymnym jądrem podmiotowości" [Dolar, 2006, s. 14], w wymiarze społecznym stanowi zaś narzędzie komunikacji i budowania relacji interpersonalnych. W zdarzeniu komunikacyjnym interpretacja głosu uwzględnia zarówno jego obraz indywidualny, jak i intersubiektywny: odczytywany w odniesieniu do Ty/Innego oraz podmiotu (Ja/mnie).

Współczesne językoznawstwo, psychoanaliza i filozofia, które przywróciły wartość i znaczenie „akustycznemu wymiarowi doświadczenia, w tym dźwiękowemu aspektowi mowy" [Michalik, 2010, s. 29], postrzegają głos w trzech różnych aspektach: językowym, zmysłowo-afektywnym oraz psychoanalitycznym [za Michalik, 2010].

Metafizyka o charakterze fonologocentrycznym dowartościowuje „żywe słowo”, które staje się pośrednikiem między rzeczywistością a poznaniem (m.in. filozofie Platona i Arystotelesa, Rousseau i Hegla, Husserla i Heideggera). To w znaku można uchwycić sens, a głos wydaje się pozostawać w bezpośredniej bliskości myśli. Dzięki 
swej „przezroczystości” głos daje możliwość uobecnienia się pojęcia, redukcja elementu znaczącego warunkuje bowiem wykorzystywanie „bezgłośnego głosu” w żywej mowie. Tak zwany zwrot Derridański czyni phoné ogniskową metafizyki (nie zaś tylko filozofii języka czy filozofii podmiotu), u której podstaw leży idea prawdy jako jedności phoné i logos. Potwierdzeniem współzależności fonocentryzmu, logocentryzmu i metafizyki obecności dla Jacques’a Derridy jest akt recepcji własnej mowy (fr. s'entendre parler - 'usłyszeć, jak mówisz' $)^{1}$ oraz sytuacja bezpośredniej rozmowy, podczas której słyszenie i rozumienie mowy zdają się utożsamiać. Podczas mówienia-słyszenia własnej mowy dochodzi do zatarcia elementu znaczącego, dzięki cze$\mathrm{mu}$ „słowo przeżywane jest jako elementarna i nierozkładalna jedność znaczonego i głosu, pojęcia i przezroczystej substancji wyrażania" [Derrida, 1999, s. 42]. W metafizyce fonologocentrycznej dostrzec można zatem deprecjonowanie phoné, który jest uprzywilejowany jedynie w tym aspekcie, w jakim podporządkowuje się i służy logosowi [por. Ihde, 1976; Welsch, 2001]. Językowo ujęty głos, utożsamiany z logosem czy też najściślej z nim związany, staje się de facto "głosem bezgłośnym”2 w słownym przekazie. Niebezpieczeństwo żywej mowy tkwi w jej afektywności, wpływającej na jasność przekazu, w takim ujęciu pożądana jest zatem redukcja zmysłowego aspektu głosu do środka wyrazu i przekazu pojęć w chwili uobecniania sensu3 ${ }^{3}$.

Jak zaznacza Mladen Dolar [1996], fonologiczna redukcja głosu do cech czysto formalnych (struktur językowych) w efekcie prowadzi do zatracenia jego materialności. Prymat uczuciowo-popędowej sfery, czyli zmysłowo-afektywnego postrzegania głosu w stosunku do ratio (m.in. Rousseau, Herder, Schopenhauer, Nietzsche), jest interesujący ze względu na jego walory estetyczne czy afektywną naturę subiektywności. W tej koncepcji głos przykuwa uwagę swoim brzmieniem, jego siła ujawnia się w natężeniu (to bezpośredni wyraz afektów), melodyjności i rytmie. Zmysłowa wartość głosu nie daje się zredukować do struktur językowych, które ożywia.

W tym drugim ujęciu podkreśla się konflikt afektywnej siły głosu i artykulacji, którą uznaje się za „umartwienie słowa w jego wokalnym aspekcie” [Michalik, 2010, s. 23], to bowiem artykulacja w znacznym stopniu ogranicza i osłabia pierwotny potencjał głosu, co w konsekwencji wiąże się z niemożnością wyrażania emocji przy użyciu tego, co zmysłowe. Uprzywilejowanie autoafektywnej, ale jednocześnie

1 Drogi autofonacyjno-audycyjne: autofonacja i autoaudycja (dośrodkowo-środkowe) są uruchamiane wówczas, kiedy nadawca odbiera własny komunikat słowny i ma nad nim kontrolę słuchową.

2 Za początek rozważań o „głosie bezgłośnym” uznaje się daimoniona Sokratesa [Michalik, 2010]. Również Ferdynand de Saussure [2002] pozbawia głos jego wartości materialnej i uznaje jego znaczenie przygodne, związane z posługiwaniem się nim w mowie.

3 Roman Jakobson [1989] zwraca uwagę na istotną dla nowożytnej lingwistyki refleksję starożytnych Greków na temat przekształcania zjawisk dźwiękowych (materialnych) w składniki języka (formalne). Redukcja głosu do form jego artykulacji występuje w fonologii. Derrida [1997] zwraca uwagę, że według de Saussure’a dźwięk w samej materialności nie ma wartości językowej, a kiedy taką zyskuje, przestaje być dźwiękowy, stanowi „substancję wyrażania”, czyli fonię. Według Dolara [1996] fonologiczna redukcja głosu do cech czysto formalnych prowadzi do „zabójstwa” głosu w jego materialności. 
idealizującej siły wokalnej słowa mówionego wiąże się z samozniesieniem znaku: „Słyszany głos jawi się przede wszystkim jako środek uwewnętrznienia (idealizacji) tego, co wyraża, jako sposób niezakłóconego odnoszenia się podmiotu do siebie" [Michalik, 2010, s. 101]. Mówiący, słysząc siebie, doznaje samopobudzenia za sprawą głosu i odnosi się sam do siebie.

Uwolnienie potencjału głosu wiąże się z jego wyzwoleniem z podporządkowania logosowi. Podkreślane w drugiej koncepcji subiektywność zmysłowa i afektywna obecność brzmiącego głosu - warunkują przekaz emocji. Stanowią też istotny element charakterystyki języka, artykulacja jest bowiem konieczna do wypełniania komunikacyjnej i referencyjnej funkcji języka.

Trzeci wymiar głosu, związany między innymi z poststrukturalistyczną wersją psychoanalizy (m.in. Lacana, Barthes’a czy Kristevej), zwraca uwagę, że w takim ujęciu "głos [jest] na poły słyszalny, na poły niemy - a zarazem najbardziej uwodzący i zniewalający" [Michalik, 2010, s. 12], manifestuje coś więcej niż tylko świadomą intencję mówiącego. W tej koncepcji następuje ekspozycja podmiotu na głos Innego. Głos jako substytut Innego jest strażnikiem immanencji podmiotu, a jednocześnie środkiem wyrazu - na co zwraca uwagę Dolar w pracy A Voice and Nothing More [2006]. Dzięki samoodniesieniu można doświadczyć siebie w głosie i przez głos, który stanowi też warunek intersubiektywności, głos porządku symbolicznego.

Próby wyjaśnienia, w jaki sposób słowo, brzmiąc, ma znaczenie, widoczne są w pracach fenomenologów, między innymi Martina Heideggera [2000], który ontologicznie dowartościowuje głos, akcentuje znaczenie wymiaru słyszalności i samego rozbrzmiewania języka, oraz Maurice’a Merleau-Ponty'ego [1996; 2006], który podważa funkcję głosu określoną przez Derridę. Dla Merleau-Ponty’ego doświadczenie ciała ${ }^{4}$ nie jest związane z bezpośrednią samoobecnością, filozof wyraźne rozróżnia to, co doświadczające i doświadczane, wewnętrzne i zewnętrzne, słyszące i słyszalne, podmiotowe i przedmiotowe, co jest ciałem własnym i ciałem obiektywnym. W takim ujęciu „głos jawi się jako sposób otwarcia subiektywności na inne subiektywności, a więc jeden z warunków konstytucji sfery intersubiektywnej. [...] Głos jest aktywną transcendencją ciała [...]" [Michalik, 2010, s. 28]. Głos to bycie-w-świecie: dzięki niemu kształtuje się relacja człowieka do świata, a jednocześnie warunkuje on relacje świata względem podmiotu. Doświadczenie głosu stanowi zatem przedmiot refleksji, która zmierza do opisu warunków odniesienia się podmiotu do siebie i świata.

4 Fr. le corps propre - 'ciało własne’ [Merleau-Ponty, 2006], fr. la chair - ‘żywa tkanka cielesności’ [Merleau-Ponty, 1996]. 


\section{Głos w wymiarze jednostkowym}

W zależności od holistycznego lub redukcjonistycznego ujęcia w wymiarze jednostkowym głos człowieka jest określany jako:

- „zaledwie ulotna wibracja wydychanego powietrza” [Michalik, 2010, s. 9];

- "dźwięk o dowolnym brzmieniu, wyemitowany w formie fali akustycznej” [Świdziński, 1998, s. 9];

- „complex phenomenon” - złożony fenomen [Verduyckt i wsp., 2011, s. 373] czy "fenomen psychoakustyczny" [Niebudek-Bogusz i wsp., 2004, s. 33];

- „nieprawdopodobny nośnik informacji o nim samym” [Płusajska-Otto, 2012, s. 111];

- „indywidualna cecha każdego człowieka, zależna od wieku, płci, stanu zdrowia fizycznego i psychicznego oraz uwarunkowań kulturowych” [Kuczkowski, 2016, s. 258];

- „najstarszy instrument świata, noszący na sobie znamiona boskości” [Kotlarczyk, 1961, s. 10];

- „instrument muzyczny [...] najbardziej delikatny i ekspresyjny” [Tarasiewicz, 2006, s. 26];

- „żywy instrument” [Bubicz-Mojsa, 2007, s. 2];

- „dźwięk, który wydaje instrument, jakim jest nasz organizm” [Płusajska-Otto, 2012, s. 111];

- „najbardziej indywidualny środek wyrazu o zdawać by się mogło nieograniczonych możliwościach" [Michalik, 2010, s. 9];

- element, który „zawiera informacje o intencjach, emocjach i stanie zdrowia nadawcy" [Kuczkowski, 2016, s. 258], czyli środek ekspresji emocjonalnej [Łastik, 2014; Binkuńska, 2016; Olszewski, Nowosielska-Grygiel, 2017, s. 91];

- „papierek lakmusowy wskazujący stan psychiczny człowieka” [Łastik, 2014, s. 14];

- „odcisk palca” [Łastik, 2014, s. 45];

- „wewnętrzne dziecko” [Łastik, 2014, s. 13];

- „przedłużenie osób” [Łastik, 2002, s. 12];

- tożsamy z człowiekiem: „głos i jego «właściciel» to jedno i to samo” [Łastik, 2014, s. 14];

- „nasz najbardziej metafizyczny «organ»” [Michalik, 2010, s. 35].

Wielość dosłownych i metaforycznych określeń dowodzi niemożności sprecyzowania istoty ludzkiego głosu oraz jego funkcji w życiu człowieka. W zależności od reprezentowanej przez autora dziedziny nauki oraz celu badań nad głosem w wymiarze jednostkowym określenia te są zorientowane biologicznie, fizycznie, psychologicznie lub ontologicznie. Na wieloaspektowy charakter głosu zwracają uwagę między innymi językoznawcy, foniatrzy, psycholodzy, akustycy, ale też antropolodzy, religioznawcy, teoretycy filmu, teatru, muzyki czy filozofowie. 
W konceptualizacjach jednostkowych często podkreślana jest subiektywność zmysłowa i afektywna. Głos jest postrzegany jako złożone zjawisko, wymagające skoordynowanych działań mechanizmów aerodynamicznych i akustycznych, które warunkują wytwarzanie dźwięków służących komunikacji. Ujmowanie głosu jako narzędzia, za którego pomocą człowiek manifestuje siebie oraz się porozumiewa, podkreśla konieczność świadomego jego wykorzystywania, troski o sprawne działanie oraz doskonalenie w użyciu. Głos pobudza ucho i mózg, w nim manifestuje się czysto fizyczna siła, ale też cechy umysłu.

Tylko podmiot, który ma bezpośredni dostęp do głosu, może kształtować z nim relacje, a przez głos wyrażać swój stosunek do świata. Wskazywaną przez autorów obecność głosu dla podmiotu (świadomość, subiektywność) można przyjąć z zastrzeżeniem niepełnego poznania - samego głosu i podmiotowej samowiedzy. Psychologiczne problematyzowanie głosu, chociażby jako „papierka lakmusowego” czy „odcisku palca”, zwraca uwagę, że głos wyraża człowieka, jest jego uzewnętrznieniem, jedynym w swoim rodzaju i niepowtarzalnym ${ }^{5}$. Umożliwia rozpoznanie mówiącego przez odbiorcę, konstytuuje jednostkową tożsamość, wskazuje stan psychiczny, nastrój lub charakter człowieka, daje pewne wyobrażenie o temperamencie i osobowości podmiotu, a nawet jego stanie psychofizycznym. Dzięki głosowi człowiek może „usłyszeć” swoje myśli i emocje - skoro „zostaliśmy skazani na niemożność wyobrażenia sobie naszej myślowości [...] inaczej niż fizycznie” [Falkiewicz, 2001, s. 221].

\section{Głos w wymiarze społecznym}

W przestrzeni społecznej głos pozwala manifestować obecność Ja, osobowość człowieka, emocje czy reakcje na bodźce zewnętrzne [Obrębowski, 2008]. Kiedy jest postrzegany w kontekście relacji podmiotu z otoczeniem (wymiar socjologiczny, uniwersalny), głos określa się w różny sposób, między innymi jako:

- „środek [, który] umożliwia kontakty osobowe” [Łastik, 2014, s. 7];

- "nośnik informacji oraz reakcji, które zachodzą między nadawcą a odbiorcą" [Kuczkowski, 2016, s. 258];

- „narząd komunikacji, tworzenia i utrzymywania relacji międzyludzkich” [Olszewski, Nowosielska-Grygiel, 2017, s. 91];

- „środek komunikacji z innymi, a także z sobą samym” [Łastik, 2014, s. 14];

- ,jest [...] ekspozycją podmiotu na głos Innego, głos porządku symbolicznego” [Michalik, 2010, s. 13];

- „substytut Innego” [Michalik, 2010, s. 13];

5 Stosowana w najnowszej technologii biometria głosowa potwierdza, że głos stanowi unikatową cechę każdego człowieka, zależną od płci, wieku, kondycji psychofizycznej, możliwości i potrzeb komunikacyjnych. 
- „narzędzie pracy” [np. Śliwińska-Kowalska, Niebudek-Bogusz, 2009, s. 5; Binkuńska, 2012, s. 9; Kisiel, 2012, s. 13; Płusajska-Otto, 2012, s. 111; Olszewski, Nowosielska-Grygiel, 2017, s. 91];

- „instrument kreowania własnego wizerunku” [Kisiel, 2012, s. 13],

- „narzędzie sprawowania władzy” [Michalik, 2010, s. 13].

Współobecność Ja i Innego (intersubiektywność) zmienia postrzeganie własnego głosu i głosu innych ludzi. Komunikacja wokalna oraz słowo ustne to swoista trans-akcja, gdyż bez interaktywnego Ty/Innego (realnego lub wyobrażonego), czyli adresata słowa, dźwięk nie działa jako słowo, przestaje być wyjaśnieniem, interpretacją czy hermeneutyką. Dla osiągnięcia porozumienia niezbędna jest zatem aktywność nadawcy i odbiorcy oraz chęć nawiązania kontaktu komunikacyjnego. Ludzki język foniczny, zespolony z człowiekiem i w człowieku zatopiony [Grucza, 1993], jest uznawany za nośnik emocji oraz intencji (w sensie zamiaru lub nakierowania na cel), narzędzie budowania relacji i manifestacja osoby w środowisku, jeden z ważniejszych filarów wspólnoty posługującej się tym samym kodem oraz kluczowe narzędzie komunikacji o charakterze pojęciowym [Kmita, 1998]. Podejmowana przez podmiot codzienna aktywność głosowa służy zatem pozyskaniu uwagi otoczenia, realizacji potrzeb estetycznych, ludycznych, grupo- i socjotwórczych ${ }^{6}$. W ujęciu intersubiektywnym głos staje się przedmiotem szczególnego zainteresowania psychologów, socjologów mowy/mówienia, filozofów, teoretyków radia, sztuki aktorskiej, logopedów, komunikatywistów czy też pragmalingwistów.

Ujmowanie głosu jako narzędzia działania komunikacyjnego to odniesienie do pierwotnej jego funkcji w bezpośrednim porozumiewaniu się. Brytyjski językoznawca John Lyons [1984] wyróżnił - w zależności od kanału przesyłania sygnałów - głosowe i niegłosowe sposoby porozumiewania się ludzi, podkreślając tym samym, że głos jest jednym z elementów warunkujących zaistnienie komunikacji ustnej: środkiem, nośnikiem, narzędziem przekazu. Na podstawie badań dotyczących analizy połączeń słowno-głosowych psycholodzy Roland J. Hart i Bruce L. Brown [1974] doszli do wniosku, że ocena atrakcyjności przekazu wiąże się głównie z charakterystyką wokalną, natomiast skuteczności - z elementami werbalnymi. Przekaz to synkretyczny komunikat złożony z elementów słownych i pozasłownych, w którego ocenie trzeba uwzględnić niuanse wokalne oraz harmonijność zestawienia sygnałów wokalnych z werbalnymi, jak również z elementami innych subkodów. Analizy użycia języka fonicznego zawsze powinny uwzględniać uwarunkowania biologiczne (dotyczące fizjologicznych, chemicznych i fizycznych procesów zachodzących w mózgu, budowy i sprawności narządów mownych) oraz konteksty psychologiczny, społeczny i kulturowy, które stanowią istotne tło językowego porozumiewania się ludzi. Cytowani autorzy dostrzegli też wykorzystanie

6 Już dla starożytnych doskonalenie głosu było elementem paidei, czyli wychowania i kształcenia człowieka. 
głosu do kreowania przestrzeni publicznej i działania w niej (por. etymologiczną bliskość „głosu” i wyrażeń odnoszących się do aktywności w sferze publicznej: zabierania głosu, głosowania, oddawania głosu).

\section{Zakończenie}

Wraz z rozwojem i popularyzacją pisma język mówiony, czyli najbardziej bezpośredni sposób wyrażania myśli, ulegał pewnej degradacji, a co za tym idzie, głos tracił na znaczeniu w swoim wymiarze materialnym, a częściowo też formalnym i symbolicznym - im bardziej artykułowany przekaz, tym głos mniej istotny dla żywej mowy, można go było oddać w piśmie. Ponowne uprzywilejowanie słowa mówionego doprowadziło do nobilitacji językowej wartości głosu w jego brzmieniu, co jednak nie oznaczało uzyskania artykułowanej jedności dźwięku i sensu w mówionym przekazie. Niemiecki filozof Johann Gottfried Herder [2002] podkreślał, że siła „żywej mowy” wynika ze słuw chowego obcowania z językiem i wyższości zmysłu słuchu nad zmysłem wzroku.

Ontologiczne dowartościowanie wymiaru słyszalności przez Heideggera nazwane zostało przez Wolfganga Welscha „rewolucją audytywną”, zmierzającą do „przezwyciężenia metafizyki" [Welsch, 2001, s. 56], do zakwestionowania dychotomii duszy i ciała ${ }^{7}$. Nadawanie, ale również słyszenie własnej mowy (autoaudycja), czyli doświadczenie własnego głosu w jego mniej lub bardziej ujęzykowionej formie, stanowi istotny element konstytuowania się tożsamości podmiotu oraz refleksji transcendentalnej, zorientowanej na opis warunków odniesienia się mówiącego do siebie oraz otaczającego go świata. Samopobudzenie poprzez głos to efekt przeświadczenia, że podmiot mówiący ma dostęp do tego, co wewnętrzne, „do czystej obecności, do źródła nieskażonego zewnętrznością? [Dolar, 2006, s. 37]. Głos potwierdza żywą obecność podmiotu (phoné wskazuje na obecność bytu), jednak doświadczenie subiektywności jest pewną iluzją własnej obecności i obecności dla siebie, iluzją poznania - ze względu na zmienność i niestabilność ciała oraz otoczenia.

Różne konceptualizacje głosu w jego wymiarze indywidualnym i społecznym wskazują, że współcześnie przedmiot zainteresowania stanowi zarówno jego warstwa materialna, formalna, jak i symboliczna. Niemożność jednoznacznego i pełnego zdefiniowania głosu oraz identyfikacja różnych jego funkcji w relacji z podmiotem i Innymi dowodzi konieczności uwrażliwienia na głos - nie tylko w jego bardziej ujęzykowionej formie podczas komunikacji bezpośredniej, ale również jako ekspresji bądź wymiany wokalnych sygnałów i znaków [por. teoria gestów fonicznych, Mayen, 1972; Kaźmierczak, 2018a; 2018b] czy istotnej składowej tożsamości komunikującego się podmiotu.

7 Do dychotomicznego podziału na to, co cielesne (materialne), radykalnie odseparowane od tego, co rozumne (świadome, myślące), przyczynił się Kartezjusz. Status przypisywany głosowi jest zależny od tego, co duchowe i cielesne: dusza ma się do ciała tak jak znaczenie do dźwięku głosu w słowie. 
Literatura

Bakke M., 2000, Ciało otwarte. Filozoficzne reinterpretacje kulturowych wizji cielesności, Poznań: Wydawnictwo Naukowe Instytutu Filozofii Uniwersytetu Adama Mickiewicza.

Binkuńska E., 2012, Higiena i emisja głosu mówionego, Bydgoszcz: Wydawnictwo Uniwersytetu Kazimierza Wielkiego.

Binkuńska E., 2016, Emocjonalne podłoże posługiwania się głosem, [w:] B. Kamińska, S. Milewski (red.), Logopedia artystyczna, Gdańsk: Harmonia Universalis, s. 297-322.

Bubicz-Mojsa A., 2007, Głos ludzki jako żywy instrument, Lublin: Wydawnictwo Uniwersytetu Marii Curie-Skłodowskiej.

Derrida J., 1997, Pozycje. Rozmowy z Henri Romsem, Juliq Kristeva, Jean-Louis Houdebinem i Guy Scarpetta, tłum. A. Dziadek, Bytom: Wydawnictwo FA-art.

Derrida J., 1999, O gramatologii, tłum. B. Banasiak, Warszawa: Wydawnictwo KR.

Dolar M., 1996, The Object Voice, [w:] R. Saleci, S. Zizek (red.), Gaze and Voice as Love Objects, Durham: Duke University Press, s. 7-31.

Dolar M., 2006, A Voice and Nothing More, Cambridge-London: The MIT Press.

Falkiewicz A., 2001, Istnienie i metafora, Gdańsk: Wydawnictwo „Tower Press”.

Grucza F., 1993, Język, ludzkie właściwości językowe, językowa zdolność ludzi, [w:] J. Piontka, A. Wiercińska (red.), Człowiek w perspektywie ujęć biokulturowych, Poznań: Wydawnictwo Uniwersytetu Adama Mickiewicza, s. 151-174.

Hart R.J., Brown B.L., 1974, Interpersonal information conveyed by the content and vocal aspects of speech, „Speech Monographs”, nr 41, s. 371-380.

Heidegger M., 2000, W drodze do języka, tłum. J. Mizera, Kraków: Wydawnictwo Baran i Suszczyński.

Herder J.G., 2002, Dziennik mojej podróży z roku 1769, tłum. M. Kurkowska, Olsztyn: Borussia. Ihde D., 1976, Listening and Voice: A Phenomenology of Sound, Athens: Ohio University Press.

Jakobson R., 1989, W poszukiwaniu istoty jezzyka, t. 2, tłum. A. Werpachowska, Warszawa: Państwowy Instytut Wydawniczy.

Kaźmierczak M., 2017, Pacjent z zaburzeniami głosu w rodzinie, „Wychowanie w Rodzinie”, t. XVI, nr 2, s. 333-346.

Kaźmierczak M., 2018a, Rodzaje i funkcje gestów fonicznych wykorzystywanych w postępowaniu logopedycznym, „Logopedia”, t. 47(1), s. 311-321.

Kaźmierczak M., 2018b, Rola gestów fonicznych w wychowaniu komunikacyjnym dzieci przedszkolnych, [w:] E. Gacka, M. Kaźmierczak (red.), Teoria i praktyka logopedyczna. Wybrane zagadnienia, Łódź: Wydawnictwo Uniwersytetu Łódzkiego, s. 131-140.

Kisiel M., 2012, Emisja i higiena głosu w pracy dydaktyczno-wychowawczej nauczyciela, Dąbrowa Górnicza: Wydawnictwo Wyższej Szkoły Biznesu.

Kmita J., 1998, Jak słowa łącza się ze światem. Studium krytyczne neopragmatyzmu, Poznań: Wydawnictwo Naukowe Instytutu Filozofii Uniwersytetu Adama Mickiewicza.

Kotlarczyk M., 1961, Podstawy sztuki żywego słowa. Instrument, dykcja, ekspresja, Warszawa: Wydawnictwa Związkowe Centralnej Rady Związków Zawodowych.

Kuczkowski J., 2016, Anatomiczno-fizjologiczne podstawy głosu, [w:] B. Kamińska, S. Milewski (red.), Logopedia artystyczna, Gdańsk: Harmonia Universalis, s. 258-275.

Lyons J., 1984, Semantyka I, tłum. A. Weinsberg, Warszawa: Państwowe Wydawnictwo Naukowe.

Łastik A., 2014, Poznaj swój głos... twoje najważniejsze narzędzie pracy, Warszawa: Wydawnictwo Studio Emka. 
Maćkiewicz J., 2008, Ja i moje ciało, czyli co to jest „bodycentryzm”, [w:] J. Bartmiński, A. Pajdzińska (red.), Podmiot w języku i kulturze, Lublin: Wydawnictwo Uniwersytetu Marii Curie-Skłodowskiej, s. 215-220.

Mayen J., 1972, O stylistyce utworów mówionych, Wrocław: Ossolineum.

Merleau-Ponty M., 1996, Widzialne i niewidzialne, tłum. M. Kowalska, J. Migasiński, R. Lis, I. Lorenc, Warszawa: Wydawnictwo Alethea.

Merleau-Ponty M., 2006, Fenomenologia percepcji, tłum. M. Kowalska, J. Migasiński, Warszawa: Wydawnictwo Alethea.

Michalik J., 2010, Filozofia i głos, Kraków: Zakład Wydawniczy NOMOS.

Niebudek-Bogusz E., Fiszer M., Kotyło P., Just M., Śliwińska-Kowalska M., 2004, Ocena parametrów analizy akustycznej głosu u zdrowych kobiet, „Otorynolaryngologia”, nr 3, s. 33-39.

Obrębowski A. (red.), 2008, Narząd głosu i jego znaczenie w komunikacji społecznej, Poznań: Wydawnictwo Naukowe Uniwersytetu Medycznego im. Karola Marcinkowskiego.

Olszewski J., Nowosielska-Grygiel J., 2017, Nowe metody diagnostyczne oceny czynności głosu dla potrzeb foniatry i logopedy, „Logopaedica Lodziensia”, nr 1, s. 91-100.

Płusajska-Otto, 2012, „Mów i nie trać głosu” - profilaktyka zaburzeń emisji głosu w pracy nauczycieli, [w:] K. Węsierska (red.), Profilaktyka logopedyczna w praktyce edukacyjnej, t. 1, Katowice: Wydawnictwo Uniwersytetu Śląskiego, s. 111-121.

Saussure F. de, 2002, Kurs językoznawstwa ogólnego, tłum. K. Kasprzyk, Warszawa: Wydawnictwo Naukowe PWN.

Skarga B., 1997, Tożsamość i różnica. Eseje metafizyczne, Kraków: Wydawnictwo Znak.

Śliwińska-Kowalska M., Niebudek-Bogusz E. (red.), 2009, Rehabilitacja zawodowych zaburzeń głosu. Podręcznik dla nauczycieli, Łódź: Oficyna Wydawnicza Instytutu Medycyny Pracy.

Świdziński P., 1998, Przydatność analizy akustycznej w diagnostyce zaburzeń głosu, Poznań: Akademia Medyczna.

Tarasiewicz B., 2006, Mówię i śpiewam świadomie. Podręcznik do nauki emisji głosu, Kraków: Wydawnictwo Universitas.

Verduyckt I., Remacle M., Jamart J., Benderitter C., Morsomme D., 2011, Voice-Related Complaints in the Pediatric Population, „Journal of Voice”, t. 25(3), s. 373-380.

Welsch W., 2001, Na drodze do kultury słyszenia?, tłum. K. Wilkoszewska, [w:] E. Wilk (red.), Przemoc ikoniczna czy „nowa widzialność”?, Katowice: Wydawnictwo Uniwersytetu Śląskiego, s. 56-74.

Wierzbicka A., 1985, Lexicography and Conceptual Analysis, Ann Arbor: Karoma. 


\section{Streszczenie}

Głos jest istotnym elementem życia człowieka. Współcześnie przedmiot zainteresowania stanowi zarówno materialna, formalna, jak i symboliczna warstwa głosu. Niemożność jednoznacznego i pełnego zdefiniowania pojęcia oraz identyfikacja różnych funkcji głosu w relacji z podmiotem i Innymi dowodzi konieczności uwrażliwienia na głos - nie tylko w jego bardziej ujęzykowionej formie, podczas komunikacji bezpośredniej, ale również jako ekspresji bądź wymiany wokalnych sygnałów i znaków czy istotnej składowej tożsamości komunikującego się podmiotu. Przytoczone w artykule konceptualizacje głosu potwierdzają, że obszary jego badania w wymiarze indywidualnym i społecznym są ze sobą ściśle związane.

\section{Abstract}

The voice is an important element of human life. Nowadays, the object of interest is both the material, formal and symbolic layer of voice. The inability to define the concept explicitly and fully and the identification of various voice functions in relation to the subject and Others proves the need for sensitivity to the voice - not only in its more linguistic form during direct communication, but also as the expression or exchange of vocal signals and signs or a significant component of the identity of the communicating entity. The voice conceptualizations cited in the article confirm that the areas of voice research in the individual and social dimension are closely related. 